RECYT

Year 23 / No 36 / 2021 / 6-13

\title{
The construction of the curricular design of the University Professor of Biology at the National University of Misiones and the formative pathway of Education for Health and the Environment
}

\section{La construcción del Diseño curricular del Profesorado Universitario en Biología de la Universidad Nacional de Misiones y del trayecto formativo de Educación para la Salud y el Ambiente}

\author{
Patricia M. Morawicki ${ }^{\star}$, Ana G. Pedrini, Alicia Tetzlaff \\ Research and Postgraduate Studies. Faculty of Exact, Chemical and Natural Sciences. National \\ University of Misiones. Félix de Azara 1552. $1^{\circ}$ Floor. Posadas, Misiones, Argentina. \\ *E-mail: pmorawicki@gmail.com
}

Abstract

Received: 03/12/2020; Accepted: 12/05/2021

\begin{abstract}
The aim of this paper is to share the results of the process of formulating the curriculum for the 2016 University Teacher Training in Biology at the Faculty of Exact, Chemical and Natural Sciences of the National University of Misiones (UNaM) based on a collective construction among various stakeholders in the educational community and especially the proposal of the formative pathway of Education for Health and the Environment (EpSyA). The research used a qualitative and interpretative methodology based on the analysis of curricular documents, institutional agreements, national regulations, interviews and classroom observations. The different instances of discussion in the reformulation of the curricular project are reconstructed chronologically, the macro-decisions in the construction of the formative path of EpSyA are analysed and the hourly loads and minimum contents of the subjects and the teaching strategies are made explicit.
\end{abstract}

Keywords: Curriculum; Education for Health and Environment; Formation; Biology Professorship; UNaM.

\section{Resumen}

La presente comunicación tiene como objetivo compartir resultados sobre el proceso de formulación del Plan de estudios del Profesorado Universitario en Biología 2016 de la Facultad de Ciencias Exactas Químicas y Naturales de la Universidad Nacional de Misiones (UNaM) a partir de una construcción colectiva entre diversos actores de la comunidad educativa y en especial la propuesta del trayecto formativo de Educación para la Salud y el Ambiente (EpSyA). En la investigación se utilizó una metodología cualitativa e interpretativa a partir del análisis de documentos curriculares, acuerdos institucionales, normativas nacionales, entrevistas y observaciones de clases. Se reconstruyen en forma cronológica las distintas instancias de discusión en la reformulación del proyecto curricular, se analizan las macrodecisiones en la construcción del trayecto formativo de EpsyA y se explicitan las cargas horarias y contenidos mínimos de las asignaturas y las estrategias de enseñanza.

Palabras clave: Curriculum; Educación para la Salud y el Ambiente; Trayecto formativo; Profesorado Universitario en Biología; UNaM.

Introduction

The aim of this paper is to describe the different moments of the collective construction, making explicit the epistemological, didactic and social foundations of the 2016 curriculum design and especially of the formative path of Education for Health and the Environment of the University Teachery in Biology (PUB) of the Faculty of Exact, Chemical and Natural Sciences (FCEQyN) of the
National University of Misiones (UNaM)

From the analysis of the information gathered through the different instruments, the results of the macro-decisions taken in the design of the PUB are presented.

A chronology of the design of the 2016 curriculum and the reconfiguration of the formative pathway of Education for Health and Environment (EpSyA), which is made up of the subjects Community and Environmental Health, Individual Health and Education for Health and 
the Environment, is carried out. It includes the selection of contents, the modifications and/or innovations proposed for the teaching of HEE from the teaching practice, the horizontal and vertical articulation in the development of the contents and the relationship with the teaching strategies prioritised in these subjects.

\section{Materials y Methods}

The methodology used in the research responds to a qualitative approach of interpretative cut and flexible design (Mendizabal in Vasilachis, 2006) (1). The following instruments were used for data collection:

1) Analysis of documentary material: The documents analysed include:

(a) Curriculum Designs: University Teacher Curriculum in Biology 2016 (Resolution ME $N^{\circ}$ 1806/16) and the Jurisdictional Curricular Designs of the Secondary School of the Province of Missions of Basic Cycle (Resolution $\mathrm{N}^{\circ}$ 638/11) and Oriented Cycle (Resolution 048/13) of the Ministry of Culture, Education, Science and Technology.

(b) National agreements and regulations: Guidelines of the National Inter-University Council (CIN), minutes of meetings of the Inter-University Council for Biology Education (CIPEB), Higher Education Law No. 24524/95, National Education Law No. 26206/06, Priority Learning Areas (CFE Resolution $N^{\circ}$. 180/12) and National Curricular Guidelines for Initial Teacher Training (MECyT Resolution No. 24/07).

c) Reports of meetings and proposals drawn up by the Coordination of the degree course and submitted to the Academic Secretariat of the FCEQyN between 2003-2016.

1) In-depth interviews: In-depth interviews were conducted with the professionals who participated in the construction of the curriculum and with the teachers responsible for the subjects Community and Environmental Health, Individual Health and Education for Health and the Environment. Interview scripts were designed combining open and closed questions, and recordings and transcriptions were made for the subsequent processing of the information.

2) Class observations: Classes of the subjects Community and Environmental Health and Individual Health of the PUB were observed in the academic cycle 2018. Prior to the observation, a matrix was designed where the variables (purpose of the class, contents, activities, class management, teaching strategies, evaluation and resources) as well as the observable aspects for each were explained. In this communication, the content and teaching strategies are analyzed.

\section{Results y Discussion}

\section{The collective construction of curriculum design...}

There are numerous definitions and conceptions about curriculum, Grundy (1998 in Álvarez, 2010: 74) (2) points it out as "A cultural construction. That is, it is not an abstract concept that has some kind of existence outside and prior to human experience; rather, it is a way of organizing a series of educational practices. From this perspective, the curriculum will emerge from the interactions of the actors in the institution and will contribute to the education of students through the establishment of particular training guidelines". Grundy expands the concept of curriculum by considering it: [...] an integral part of the culture of society and points out that, in order to understand the meaning of any set of curriculum practices, they have to be considered both as elements emerging from a set of historical circumstances and as reflections of a particular learning environment (1998, p. 76, in Alvarez, ob.cit.) (2). The reformulation of the syllabus for the Biology degree course began in 2003 on the basis of a proposal submitted by the course co-ordination. It was drawn up on the basis of the evaluation of the development of the 1992 syllabus (with amendments in 1997 and 2000). In coordinator's word, Mgter Ramos, "Based on the experiences gathered in that project, we believed in the need to persist, expand and improve this teacher training work. We knew that this task was not easy, that it entailed an enormous challenge for the teachers responsible, as they had to learn to share their work, avoiding the sectorization of disciplines and assuming a shared responsibility in the development of non-traditional educational proposals [...]

Organizing the curriculum in this way led us to consider the interdisciplinary approach to global problems in relation to the Environment, Health and Education, so that there would be a constant integration of sequenced learning and with horizontal articulation between them. The dynamics of the curriculum itself allowed the necessary adjustments to be made in accordance with the implementation of current educational laws and at the same time the incorporation of advances in the area of Natural Sciences and Health (Interview Ramos, 2017).

In 2004, the FCEQyN pedagogical area was established. This renewed team of teachers generated an innovative proposal for pedagogical training and practices which, although it was not implemented, served as an input for the design of the 2016 plan. Based on workshops held with teachers from the Biology, Mathematics and Physics faculties.

"... it was agreed that the starting point was to understand education as "educational practice", a type of social practice exercised by specific social agents (students-teachers) acknowledging that this practice is guided by a global objective of education, modelled within 


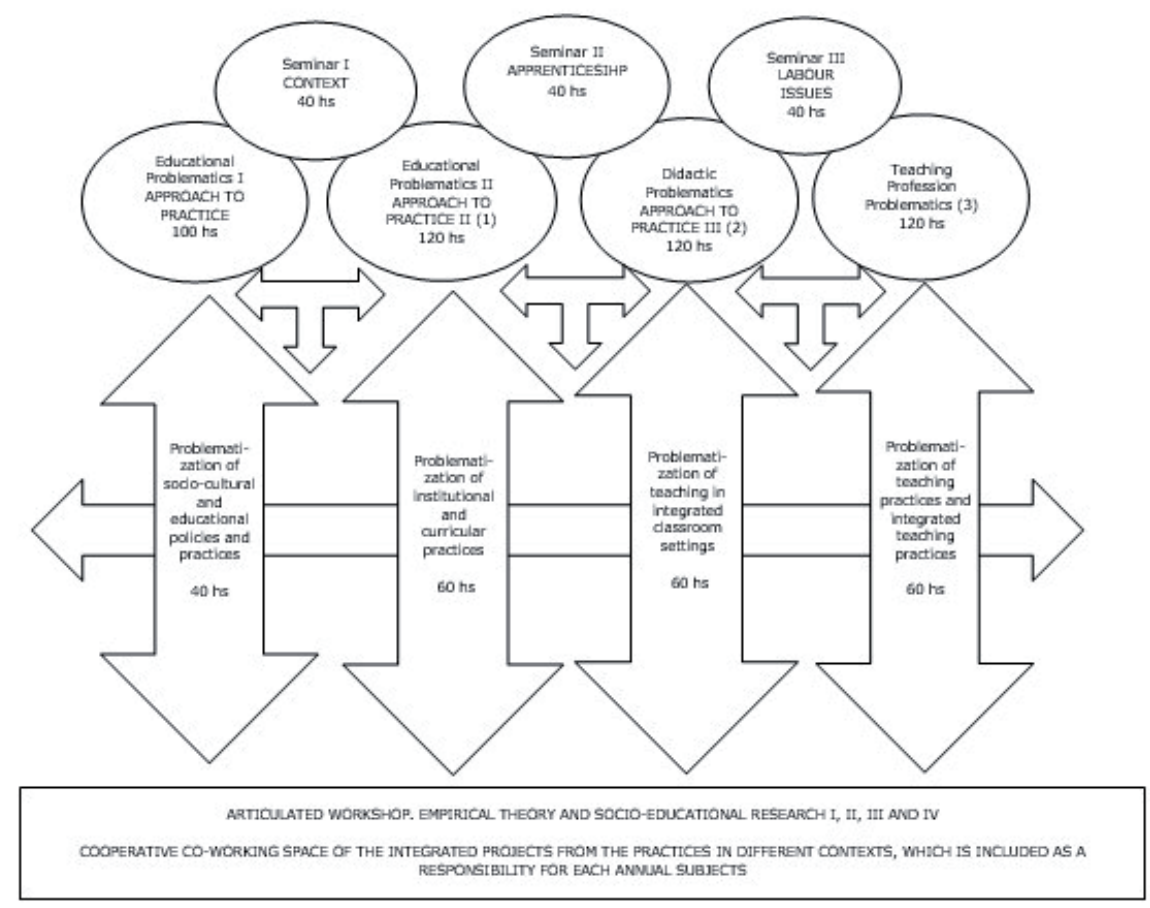

Figure 1: Outline of pedagogical training and internships for Biology, Mathematics and Physics Teacher Training Courses.

the framework of a society and in a specific socio-historical context $[\ldots]$. It was proposed to work with the "mother objective of problematizing the practices that constitute us and above all that of the teacher profile, who is desired as a subject aware of the movement and dynamism of the world, as this will allow them to see and see themselves as historical actors situated and in the process of resignification" (Institutional document, 2005) (Figure $\mathrm{n}^{\circ} 1$ ) (Figure $\mathrm{n}^{\circ} 1$ ).

In 2005, FCEQyN Biology Department presented an alternative proposal to the one it had been working on during the period 2003-2005. The design proposed changing the name of the degree to Professor of Biological Sciences, based mainly on the recovery of a solid disciplinary training from the biological field.

The minimum content required by the Ministry of Education and the incipient recommendations of the Inter-University Council for Higher Education in Biology (CIPEB), which drew up the standards for Biology degrees, were used as a reference framework. The knowledge suggested covered the general areas of Mathematics and Physics, Basic and Applied Chemistry and Biology (General, Cellular, Molecular, Genetics, Ecology, Zoology and Botany).

The curriculum designed had biological contents with regional and national interest. The number of subjects in disciplinary training was increasing, resulting in a growth in the hourly workload and in the fragmentation and specialization of curricular content. Furthermore, an additional academic offer was presented to the curriculum mesh of Specific Training, optional subjects and biological refresher courses that would allow the student to complete their training, to guide and channel their particular concerns or those of the environment in which they work, enabling comprehensive training and access to specializations

In relation to the area of $\mathrm{PHE}$, the proposal maintained the subjects Public Health, Personal Health and Health Education in the second, third and fourth years respectively, keeping the timetable and removing the subject Educational Project, which enabled the development of socio-community intervention practices. It also proposed the four-monthlyisation for all the subjects with the exception of Professional Teaching Practice.

In both proposals, there was a power struggle among teachers who belonged to different fields and disciplines, which generated tensions and negotiations, as De Alba (1995:59) (3) recognizes when he characterizes the curriculum as a "synthesis of cultural elements (knowledge, values, beliefs, habits) that make up an educational policy proposal"... "The synthesis implies the nature of the struggle (expressed in different ways) that takes place, both in the initial shaping of a curriculum and in its development and evaluation" (p. 61, ob. cit.) (3)

In the period 2010-2014, the Coordination of the Biology Department created spaces to incorporate students and graduates into the curriculum discussion as it is shown in the following testimony: "...listening to different voices will allow us to identify the needs of students and graduates in order to improve the proposal...". (Interview with course director 2010-2014).

In 2010, students were invited to the " $1{ }^{\text {st }}$ Conference for the integration and analysis of the syllabus of the Biology Teacher Training Course" with the aim of analyzing and reflecting upon the strengths and weaknesses of the current syllabus, learning about and discussing over the minimum 
contents and standards suggested by the CIPEB interuniversity council for higher education in biology with a view to the possibility of accreditation of the Teacher Training Courses, as well as drawing up and agreeing on improvement proposals.

Among the difficulties, they pointed out certain deficiency in specific training (molecular biology); a very demanding system of correlativity; lack of content integration, excessive time load in the 2 nd and 3rd years; courses length; amount of subjects in the 3 rd year that have Animal Biology as correlatives; absence of social subjects such as Psychology, Philosophy, Epistemology; late initiation into teaching practice; lack of class simulation; non-specific subjects (e.g. Mathematics) which are annual when they could be four-monthly, leaving the annual timetable to a specific subject; assessment systems (evaluation methods, requirements, grading format, continuousness in assessment and accreditation criteria, inconsistency in what is said during the tutorial sessions, etc.) (Internal Coordination Report, 2011).

During 2011 and 2012, surveys were carried out among graduates of the current Plan. The common difficulties pointed out referred to "the time load in the second year; the closed and inflexible system of correlatives; lack of integration between disciplinary and didactic content and the absence of training in ICT" (Internal Coordination Report, 2013).

These problems highlighted by students and graduates were analysed and considered in the formulation of the new syllabus, as well as the actual course time due to the large amount of content in relation to the planned years and the impossibility of passing some subjects, which hindered the students' progress.

In 2013, Oudín published the results of his research on the learning of the students of the Biology Teacher Training Course, revaluing the EpS axis as reflected in the following testimony: "They always recover the subjects of the Health axis in their narratives, because of the formative spaces they provide... I observe that they constitute formative activities that situate them as subjects who can: re-know themselves, discover themselves, transform themselves and develop their attitudes and aptitudes and defy the reproductive gaze of passive copying" (Oudín, 2013) (4). These findings served as a guide to sustain the training strategies in the new plan. In the same year, based on the contributions of the various stakeholders involved (Department, subject teachers, degree coordination, students, graduates), a proposal was drawn up to modify the study plan which, after analysis, review and approval by the various University bodies, was submitted to the Ministry of Education in 2015.

Finally, after a long process of negotiations and adjustments, it was approved by Resolution ME $\mathrm{N}^{\circ} 1806 / 16$, with the new name: University Teachery in Biology.
National agreements and regulations were taken into account in the elaboration of the PUB curriculum design, namely:

- Guidelines of the National Inter-University Council (CIN) approved in March 2013 which explain the standards for the accreditation of university degree courses in Biology.

- Minutes of meetings of the Inter-University Council for Biology Education (CIPEB) for the development of accreditation standards for Article 43 degrees. It should be noted that in the proposal for the minimum content of the EHSE standards, the contribution made by the UNaM Biology Department (2009-2013) has been considered, positioning the EHSE area on an equal footing in relation to other disciplines.

- Higher Education Law $N^{\circ} 24.521 / 95$ (5): Article $N^{\circ}$ $28^{\circ}$ paragraphs a, b, c, $\mathrm{d}$ and e referring to the basic functions of university institutions were considered.

- Ley de Educación Nacional $N^{\circ} 26206 / 06$ (6) en particular el Artículo $\mathrm{N}^{\circ} 11$ (inciso b, k y s) en el cual se explicitan los fines y objetivos de la política educativa nacional y el artículo $\mathrm{N}^{\circ} 71$ que establece las características de la formación de los profesionales docentes.

- National Education Law No 26206/06 (6), in particular Article 11 (b, k and s) which sets out the aims and objectives of national education policy and Article 71 which establishes the characteristics of the training of professional teachers.

- Priority learning areas (Resolution CFE - Federal Education Council- $\left.N^{\circ} 180 / 12\right)$ where the science teaching situations to be implemented by teachers are established.

- National curricular guidelines for the initial teacher training, especially for Biology Teacher Training, which were drawn up in 2010 by the National Institute for Teacher Training (MECyT - Ministry of Education, Science and Technology, Resolution $\mathrm{N}^{\circ}$ 24/07).

- Curricular designs for the Basic and Oriented High School of the Province of Misiones that were developed by the Ministry of Culture, Education, Science and Technology between 2009 and 2012.

The PUB (university teachery in biology) syllabus is organized into four fields: Disciplinary training, General training, Pedagogical training and Practical teacher training, which are visualized in the objectives and profile of the degree. As it can be seen in the formal structural aspects of the document, the EpSyA training pathway is included in the field of disciplinary training. The syllabus states that the training guarantees the acquisition of scientific and didactic knowledge and the development of research skills in order to contribute to the scientific and social development of the country by understanding the different phenomena of the biological world, environmental and health problems and the socio-educational field. 
This is in line with the proposal of a professional profile for disciplines in the fields of biology, health, environment and education in which intervention is based on a sociocritical model in both the scientific and educational spheres, problematizing reality and critically analyzing the local, national and international environment. Likewise, the intention is to train professionals with the capacity for interdisciplinary and intersectoral work, seeking a systemic understanding of the complexity of both the natural and social world.

In the rationale of the 2016 Plan, it is proposed "... to capitalize on the numerous STS\&A relationships, as these stimulate reflection by bringing science into tension with human, ethical and political issues, thus contributing to the public aspect of science. Scientific research and its technological applications are not isolated from the society in which they are embedded, which generates wide-ranging discussions on the social role of science and its links with various actors and interlocutors. Teacher training must strengthen the conception of science as part of culture, and as such, subject to the ups and downs and social considerations that govern it"... "A new teaching role is proposed, characterized by the use of know-how and the ability to establish and conduct personal interaction with students from the disciplinary and didactic aspects" (Resolution ME1806/16) (7). These expressions would indicate the prevalence of a sociocritical political-educational proposal whose interests show a teacher training with a clear position on the meaning of education for the scientific enculturation of citizenship and community participation.

\section{Health and Environmental Education training pathway (EpSyA)}

The construction of the educational pathway of Health and Environmental Education training pathway (EpSyA) in the 2016 curriculum design is related to the professional development of the teachers responsible for the discussion and drafting of the curriculum, who have been trained in the area of health and shared the development of some of the subjects with $\mathrm{Mg}$. Ramos, one of the managers of the 1992 Curriculum and pioneer in the incorporation of EpS and Sex Education in university education. The 1992 Plan's EpS axis, made up of the subjects Public Health, Personal Health and Health Education, was based on conceptions of Health as wellbeing and EpS as an individual and social right and as a complex social practice. Health promotion was upheld as a basic principle (Resolution HCS No. 059/92)(8).

In 2008, one of the teachers involved began research as part of a master's thesis entitled "Impact of Health Education training on graduates of the National University of Misiones by analyzing their practices during their professional development as teachers" (Morawicki,
2015). This arises from the need of the teaching team to review their own practices in the area of health and teacher training and to analyze the impact of the HEE training of secondary school teachers, as the following testimony shows "training in the area of health is very significant in the teaching profession, the concern is: What do they teach at school from everything they learn in the degree course? What do the graduates manage to transfer to the institutions from the approaches, strategies... Are participatory and dialogical methodologies used in the training? What are the ways of teaching? How do the media influence the adoption of healthy behaviours? What role does the school play? (Interview to Morawicki, 2017).

The research data made it possible to reflect upon the action, from the curricular point of view, to review content, methodology, theoretical framework, and to incorporate elements of the social and educational reality that enable the development of skills in students to adapt proposals to the context, taking into account social problems. The results show that "in the teaching practices of the undergraduates, two conceptions of health were identified: the biomedical (with greater emphasis on prevention) and the holistic (from the perspective of the individual and their environment), with a marked predominance of the first approach. Despite the fact that UNaM teachers are trained under the paradigm of the second approach, it is observed that the biomedical model conditions the teaching of Health Education. Only some non-traditional strategies were observed that made it possible to approach the holistic conception of health with democratic and participative didactic proposals, which tend to reconstruct the values and experiences of the students, involving cultural and social aspects in relation to the context of their community".... "Questions remain as to whether the training received has made it possible to break down the matrices installed in the students, so that they can confront the biomedical model of health and health education centred on prevention, which is strongly installed in the institutions and which in many cases conditions teaching practice, preventing the incorporation of innovative ways of teaching or the creation of different spaces for teaching. These deep-rooted models generally end up nullifying the intention to change of teachers who are starting out" (Morawicki, 2015:146 and 150) (9).

In 2009, there was a change in the heads and teaching teams of the three subjects in the EpS area. This brought about the incorporation of modifications, innovations, theoretical updates and proposals for the selection, sequencing and organization of content that later formed part of the 2016 Syllabus, as the head of the Public Health and Personal Health subjects says “... based on my history as a member of the subjects under Professor Ramos, we were able to evaluate the diversity of topics that were important for the training of a teacher of Biology in the contemporary world. The characteristic of these courses 
is that they require constant updating in order to address health issues of social and educational interest... One of the decisions I took was the equitable development of the different modules that make up Personal Health, where there was a preponderance of content on sexuality and sex education. On the other hand, the subject of Public Health was taught by different specialists, resulting in fragmented and isolated content, and in some cases overlapping; in this respect, a backbone was organized to link the proposed content". (Interview to Pedrini, 2017)

In EpSyA formative trajectory, the classroom workshop continues to be used as a methodological strategy, which was recognized as a significant experience by students and graduates as well as an opportunity to work with the body, as mentioned by Oudín, ob cit.) (4) in his research "The workshop gains relevance as a work method which, in the opinion of those who undertake the experience, is formative in itself" ... "They emphatically mention in their narratives, on the one hand, the work they carry out with the body from different proposals such as: dramatizations, games, teaching, etc. It seems that carrying out these experiences puts them in a situation of exposure, they are mobilized on different levels: personal, emotional, pedagogical-didactic, social and also in epistemological aspects".

Teaching is presented in various formats, such as: research work with users of health systems and with young people and adolescents; design and coordination of workshops; diagnosis, formulation and implementation of self-managed socio-community projects. The cinematographic resource is incorporated as an objectifying element in the analysis of substantive theoretical categories for the promotion of health and the enculturation of the undergraduates.

Regarding the above, we consider that the new curricular proposal, apart from recovering the ideology of the 1992 Syllabus, maintains both the practical procedural aspects with respect to EpS - placing value on systemic and democratic training in the framework of health promotion from a teacher profile as a health promotion agent and environmental educator who recognizes the interdependence between factors as a key element for understanding the dynamics of the biosphere - and the methodological approach of a participatory nature, whose main teaching strategy is the classroom-workshop.

The health promotion approach based on a broad conception of the health-disease process and its determinants is becoming more complex. It incorporates the concept of health empowerment defined "as a process of social action that promotes the action of subjects" (Kornblit and Méndez Diz, 2000:45) (10). This paradigm emphasizes the active engagement of students in the construction of this knowledge and the development of capacities to carry out the actions they undertake based on this knowledge and the stimulation of critical thinking, commitment and imaginative creation.

In accordance with the proposal of standards for the accreditation of Biology Teacher Training Courses, which suggested the organization into fields subdivided into organizational axes centered on the presence and progression of certain conceptual thematic nuclei, the design criteria taken into account were the axes described in the 1992 plan as formative paths. In addition, the names of the subjects, the hourly loads, the year of study and the minimum contents were modified.

The EpSyA training pathway, as detailed in Table $\mathrm{N}^{\circ} 1$, is made up of the subjects Community and Environmental Health, Individual Health and Education for Health and the Environment, which are taken in succession.

Table 1: Subjects of the formative path in EpSyA (Plan 2016).

\begin{tabular}{|c|c|l|}
\hline Subject & $\begin{array}{c}\text { Year and } \\
\text { timetable }\end{array}$ & \multicolumn{1}{c|}{ Minimum content } \\
\hline $\begin{array}{c}\text { Community and } \\
\text { environmental } \\
\text { health }\end{array}$ & $3-75$ hs & $\begin{array}{l}\text { Health: conceptions. Health-disease process. } \\
\text { Public health. Health determinants. New } \\
\text { health promotion. Health systems. Health } \\
\text { actions. Epidemiology. Environmental } \\
\text { health. Environmental sanitation. Health } \\
\text { education. Food security and sovereignty. } \\
\text { Food and nutrition education. }\end{array}$ \\
\hline $\begin{array}{c}\text { Individual } \\
\text { health }\end{array}$ & $3-75$ hs & $\begin{array}{l}\text { Life cycle. Subjectivity and mental health. } \\
\text { Promotion and prevention in individual } \\
\text { health. Risk and resilience. Sexuality. } \\
\text { Models of sexual education. Problematic } \\
\text { substance use. Addictions and multi- } \\
\text { causality. Models of prevention of } \\
\text { consumption. Problems of violence. Conflict. } \\
\text { Coexistence. Adolescence and youth. }\end{array}$ \\
\hline $\begin{array}{c}\text { Health and } \\
\text { environmental } \\
\text { education }\end{array}$ & $4-75$ hs & $\begin{array}{l}\text { Health education and environmental } \\
\text { education: epistemological conceptions } \\
\text { and didactic models. Health education and } \\
\text { environmental education in school and } \\
\text { community settings. Didactic strategies in } \\
\text { the teaching of health and environmental } \\
\text { education. Didactic materials. }\end{array}$ \\
\hline
\end{tabular}

In relation to the minimum content proposal (2016 plan), knowledge was incorporated both from the environmental area in the framework of CTSA relations and from the field of health linked to current social problems (risk and resilience, problematic substance use, violence, among others). Likewise, new perspectives on adolescence and youth, recognizing the heterogeneous nature of these categories and the singularity of the subjects that make them up.

In relation to the subject Community and Environmental Health, formerly known as Public Health, the contents are approached from the perspective of the new Health promotion (Cereznia, 2003) (11): “a clearer and more precise way of thinking about Public Health is to work on what is community health and environmental health, seeking not to represent so much the concept of public health linked to sanitation but with a projection of what is the new health promotion where it is thought with a great participation of the community and from the complexity of the environment as a determinant factor of health". (Interview to Pedrini, 2018). In relation to the contents of the subject, we recovered the constructions 
of the programmes of the 1992 plan together with its amendments.

In the case of Individual Health, formerly Personal Health, its name is based on Murga's theoretical category of individual health (in Perea Quesada, 2004) (12). The teacher in charge, states that "the concept of personal health is not described in the bibliography while the individual health category does exist (...) As the curricula are a national and international publication and in some way must allow other readers to understand the cut that is made, it was decided to use the name Individual Health" (Interview to Pedrini, 2018).

The subject Health and Environmental Education, previously called Health Education, has changed its timetable and name, due to the incorporation of Environmental Education (EE) content. The person in charge states that "as there was no EE subject, these contents were incorporated into HEE with teaching strategies and specific bibliography, which allow for the integrated work between HEE and EA" (Interview to Morawicki, 2018).

It is characterized by addressing historical and epistemological issues of education, health and environment as a construction with common foundations over time. The structure and objectives of the subject are based on the contents proposed in the 1992 Plan "...a characteristic is that; in addition to the disciplinary contents of the subject (such as the history of Health Education or school management models), which has been developed in Community and Environmental Health and Individual Health, is recovered to design teaching and, mainly, methodological proposals" (Interview to Morawicki, 2018).

As the classroom workshop is the didactic strategy used throughout the whole of the EpSyA training course, the classes are not fragmented into theoretical and practical classes and they would enable an integrated and reflective approach to knowledge, promoting individual and collective learning processes among the members of the group.

Some of the teaching strategies implemented in the subjects of Community and Environmental Health and Individual Health are related and becoming more complex. In Community and Environmental Health, social enquiry work is proposed, focusing on the preparation of surveys and in Individual Health on interviews. In the first subject, the working universe is made up from the local private or public health system users and; in the second subject, the youngsters and certain social problems are linked to this stage of the life cycle. In relation to this, the teacher points out "...there is autonomy in the sense that it is the students who construct these research projects, setting out the problem, the objectives and other components. We do not propose what to investigate, so that they can find out by themselves, confront their own assumptions and representations. Consequently, we work on the process of carrying out a diagnosis, an investigation" (Interview to Pedrini, 2018). Another strategy used in Community and Environmental Health is role-playing.

In Individual Health, film is proposed "as that epistemic element which allows us to think about situations that we did not see or that we do not think of that can be analysed in the light of theory" (Interview to Pedrini, 2018).

The strategies incorporated in the subject Health and Environmental Education are the analysis of scientific controversies and the analysis of radio, graphic and television journalistic material. Strategies for thinking about teaching are proposed. In teacher's words, "class simulations are proposed where students plan the contents selected from the DCJ and prepare workshops". One of the proposals that is closest to school reality are the workshops on Adolescence and Sexuality that take place in a secondary school "it is the first intervention they have with real students... creating, designing and putting the proposals into practice...". (Interview to Morawicki, 2018)

\section{Conclusions}

From the analysis carried out through various instruments in the research on the University Teachery in Biology 2016 it is concluded:

Regarding the Study Plan:

- In the process of curriculum reformulation, the historical journey and the collective and democratic construction have been highlighted by recovering the voices of different institutional actors: teachers, students and graduates.

- The epistemological and didactic approach of the 1992 Plan and its amendments would persist in 2016 with variations due to the disciplinary updating of the field of Health and Teacher Training. This could be due to the professional development in EpS of the teachers involved in the curricular reformulation.

- The EPSyA training pathway has its origins in the EpS axis of the 1992 plan and would strengthen professional development as a health promotion agent and environmental educator.

Regarding to the contents selected for the training pathway in EpSyA:

- They are formulated in accordance with the standards for Biology Teacher Training Courses established by the CIN and in line with the Jurisdictional Curricular Designs for Secondary Education. In addition, they recover and update the 1992 curricular proposal (with modifications in 1997 and 2000).

- The contents selected respond to social and sociocultural demands, contributing to the differentiation of the institution's graduates in response to the profile set out in the study plan.

- In the subject Community and Environmental 
Health, the contents are approached from the point of view of the new health promotion that includes community participation and the complexity of what the environment represents as one of the determining factors of health.

- The subject Individual Health focuses on the concept of the social subject from the perspective of mental health and health promotion.

- In the subject Education for Health and the Environment, disciplinary and didactic knowledge is re-signified for the design and implementation of classroom or community proposals.

In terms of the teaching strategies proposed, it is observed:

- The participatory methodological approach.

- The teaching strategy used in all subjects of the EpSyA training pathway is the classroom workshop. In addition, role-playing, enquiry work, analysis of socio-scientific issues and journalistic material, film, among others, are used.

\section{Bibliography}

1. Vasilachis de Gialdino, I.; Ameigeiras A.; Chernobilsky, L.: Giménez Béliveau, V.; Mallimaci, F.; Mendizábal, N.; Neiman, G.; Quaranta, G. y Soneira, A. Estrategias de investigación cualitativa. Barcelona:Gedisa. 2006.

2. Álvarez, M. Diseñar el currículo universitario: un proceso de suma complejidad Signo y Pensamiento, vol. XXIX, núm. 56, pp. 68-85 Pontificia Universidad Javeriana Bogotá, Colombia. 2010. Disponible en: http:// www.redalyc.org/articulo.oa?id=86019348004 (consultada el 21/7/20).

3. De Alba, A. Curriculum: crisis, mitos y perspectivas. Miño y Dávila Editores. Buenos Aires. Argentina. P. 1995.
4. Oudín, M. Las representaciones acerca de las experiencias que propician aprendizajes para el desarrollo profesional docente, que tienen los estudiantes del último año del Profesorado en Biología de la Facultad de Ciencias Exactas, Químicas y Naturales. Universidad Nacional de Misiones (UNaM). Tesis Universidad Nacional del Litoral. 2013.

5. Ley de Educación Superior $\mathbf{N}^{\circ} \mathbf{2 4 . 5 2 1 / 9 5}$. Disponible en: www. me.gov.ar/consejo/cf_leysuperior.html (consultada el $15 / 3 / 19)$

6. Ley de Educación Nacional $\mathbf{N}^{\circ}$ 26.206. Disponible en: http:// www.me.gov.ar/doc_pdf/ley_de_educ_nac.pdf (consultada el 15/3/2019)

7. Resolución ME № 1806/16. Plan de Estudios del Profesorado Universitario en Biología. Ministerio de Educación.

8. Resolución HDS 059/92. Plan de estudio Profesorado en Biología. FCEQyN. UNaM.

9. Morawicki, P. Las prácticas docentes en Educación para la Salud. En egresados de la Universidad Nacional de Misiones (Argentina) Alemania: Editorial Académica Española. 2015.

10. Kornblit, A. y Méndez Diz, A. La Salud y la Enfermedad: Aspectos biológicos y sociales. Buenos Aires: Aique. 2000.

11. Czeresnia, D. y Machado de Freites, c. Promoción de la Salud: conceptos, reflexiones, tendencias. Bs As: Lugar Editorial. 2003.

12. Perea Quesada, R. Educación para la Salud. Reto de nuestro tiempo. Madrid: Díaz de Santos S.A. 2004. 